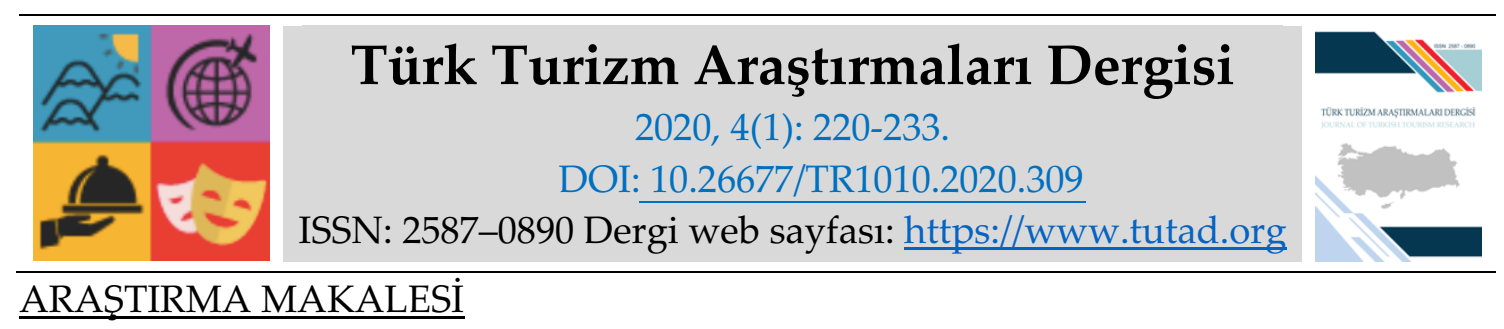

\title{
Mağara Turizminin Akçakoca Turizmine Etkileri: Fakıllı Mağarası Örneği
}

Doç. Dr. Burhanettin ZENGİN, Sakarya Uygulamalı Bilimler Üniversitesi, Turizm Fakültesi, Sakarya, e-posta: bzengin@sakarya.edu.tr ORCID: https://orcid.org/0000-0002-6368-0969

Mert EKER, Bilim Uzmanı, Sakarya Uygulamalı Bilimler Üniversitesi, Lisansüstü Eğitim Enstitüsü, Sakarya, e-posta: merteker@outlook.com ORCID: https://orcid.org/0000-0002-5208-6171

$\ddot{O} z$

Fakıllı Mağarası sahip olduğu doğal güzellikleri, atmosferi ve havasıyla her yıl binlerce turist tarafından ziyaret edilmektedir. Ancak yıllık ziyaretçi sayısı göz önüne alındığında mağara henüz hak ettiği ziyaretçi sayısına ulaşamamıştır. Bu bağlamda araştırmamızın amacı, Fakıllı Mağarası'na yönelik turizm talebini etkileyen faktörleri belirleyerek, bu talebin arttırılmasına yönelik öneriler sunmaktır. Bu amaca ulaşmak için iki yöntem kullanılmıştır. Öncelikle katılımlı gözlem yöntemiyle mağara ve yakın çevresi hakkında bilgi toplanmıştır. Daha sonra ise nitel araştırma yöntemlerinden görüşme tekniği kullanılarak Akçakoca'nın turizm paydaşlarından konu hakkında bilgi sahibi olan 25 katılımcıya yarı yapılandırılmış mülakat uygulanmıştır. Elde edilen veriler yardımıyla GZFT analizi matrisi oluşturulmuştur. Araştırma sonuçlarına göre Fakıllı Mağarası'nın yerleşim yerine ve şehirlerarası yol güzergâhına yakın olmasının ve Akçakoca'ya olan turizm talebinin giderek artmasının, mağaraya olan turizm talebinin arttırılması konusunda yürütülecek olan faaliyetlere yön vermesi açısından önemli olduğu görülmüştür. Öte yandan mağarada yeteri kadar bakımların yapılmamış olduğu ve tanıtım ve pazarlama faaliyetlerinde yetersiz kalındığı tespit edilmiştir. Bu vb. hususlar, mağaranın turizm talebini olumsuz etkileyebilecek diğer önemli sonuçlardır.

Anahtar Kelimeler: Akçakoca, Mağara Turizmi, Mağara, Turizm Talebi.

Makale Gönderme Tarihi: 30.08 .2019

Makale Kabul Tarihi: 04.01.2020

\section{Önerilen Atıf:}

Zengin, B. ve Eker, M. (2020). Mağara Turizminin Akçakoca Turizmine Etkileri: Fakıllı Mağarası Örneği, Türk Turizm Araştırmaları Dergisi, 4(1): 220-233.

(c) 2020 Türk Turizm Araştırmaları Dergisi. 


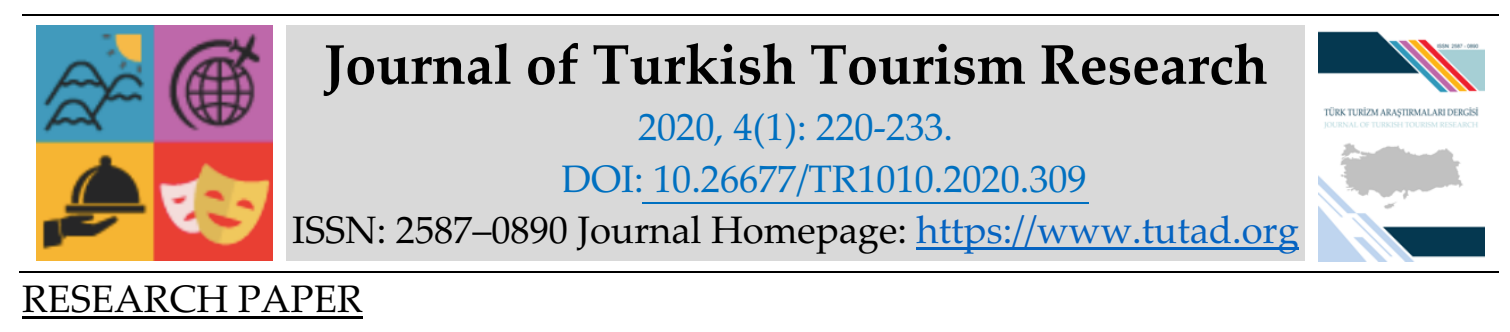

\title{
The Effects of Cave Tourism on Akçakoca Tourism: Fakıllı Cave Example
}

Associate Prof. Dr. Burhanettin ZENGIN, Sakarya University of Applied Sciences, Faculty of Tourism, Sakarya, e-mail: bzengin@sakarya.edu.tr ORCID: https://orcid.org/0000-0002-6368-0969

Mert EKER, Bilim Uzmanı, Sakarya University of Applied Sciences, Graduate Education Institute, Sakarya, e-mail: merteker@outlook.com

ORCID: https://orcid.org/0000-0002-5208-6171

\begin{abstract}
With its beauty, atmosphere and air that it has, The Fakilli Cave, is visited by thousands of tourists every year. But when the annual average of visitors has been considered the Cave cannot reached the number of visitors that it deserved, yet. In this context the aim of our research is, with determining the factors that affect the tourism demand for the Fakilli Cave, to provide suggestions for the increase of that demand. Two methods have been used for achieving that aim. Firstly, with participatory observation method information about the Cave and its surroundings has been collected. Later a semi-structured interview has been conducted to 25 participants who had information about the subject from the Akçakoca's stakeholders of tourism using interview technique from qualitative research methods. With help of the data obtained, the SWOT analysis matrix was created. According to results of the research it has seen that it is important in terms of the Fakilli Cave's closeness to the settlement and inner-city road route, the activities to increase tourism demand for the Cave. On the other hand, it has been determined that the Cave had not been adequately maintained and promotion and marketing activities had been failed. Those and similar cases are the other significant results that would be able to affect tourism demand of the Cave in a negative way.
\end{abstract}

Keywords: Akçakoca, Cave Tourism, Cave, Tourism Demand.

Received: 30.08 .2019

Accepted: 04.01.2020

\section{Suggested Citation:}

Zengin, B. and Eker, M. (2020). The Effects of Cave Tourism on Akçakoca Tourism: Fakıllı Cave Example, Journal of Turkish Tourism Research, 4(1): 220-233.

(C) 2020 Türk Turizm Araştırmaları Dergisi. 


\section{Gíriş}

Mağara, karstik alanlarda kireç taşlarının erimesiyle oluşan, büyük, birbirine koridorlarla bağlı yer altı kovukları olarak tanımlanmaktadır (https://sozluk.gov.tr/). Tanımda da bahsi geçen kireç taşı alanlarının fazla olması neticesinde Türkiye'nin mağara oluşumu için uygun bir coğrafya olduğu söylenebilir (Öcal ve Özcan, 2013: 424). Öyle ki dünyadaki diğer ülkelerle karşılaştırıldığında sahip olduğu yaklaşık 40.000 adet mağara ile Türkiye, mağara bakımından oldukça zengin bir ülke olarak nitelendirilebilir. Özellikle Batı ve Orta Toros Dağlarında karstik alanlar yoğun olarak bulunmaktadır (https://yigm.ktb.gov.tr/).

Geçmiş yıllarda depolama, sığınak ve korunak gibi farklı alanlarda kullanılmış olan mağaraların günümüzde bunlara ek olarak hastalıkların tedavi edilmesi ve zirai üretim gibi çok çeşitli kullanım alanları bulunmaktadır. Diğer bir yandan turizm faaliyetlerinin giderek çeşitlenmeye başlamasıyla, mağalar turistik amaçlarla da kullanılmaya başlanmıştır (Bekdemir vd., 2004: 311, Arpacı vd., 2012: 61). Yer aldığı bölgedeki topluma ekonomik, sosyal ve çevresel faydalar sağlayacağından dolayı mağaralar, uygun bir şekilde kullanıldığında ve geliştiğinde turizm endüstrisi için önemli olmaktadır (Okonkwo vd., 2017: 16). Doğal yollarla oluşmuş mağaralar, sahip olduğu gizemli atmosfer ve doğal güzellikler ile potansiyel bir turizm kaynağı olarak değerlendirilebilir (Kim vd., 2008: 300).

Mağaraların turizm kapsamında ilk kullanım amaçları gençlerin macera arayışı ve keşfetme duygularına dayansa da ilerleyen yıllarda mağaralar doğal ve kültürel değerlerin korunmasına katkıda bulunması ve turizmin sürdürülebilirliğine yardımcı olması sebebiyle birçok kişinin ilgisini çekmeye başlamıştır (Akdağ, 2013: 180). Sahip oldukları doğal oluşumlarla ve güzelliklerle doğa turizminin veya turistleri cezbedebilecek ekoturizmin bir parçası olmasının yanında (Rindam, 2014: 1) mağaralar, macera ve sağlık arayışı ya da kültürel amaçlı geziler olmak üzere pek çok farklı alanda da insanları kendine çekebilmektedir.

Günümüzde yaşam standartlarının yükselmesi, seyahat etmeye ayrılabilecek boş vaktin artması, kentleşmenin ve iş yaşamının insanlarda oluşturduğu sıkıntı ve stres gibi nedenlerin etkisiyle turistlerin istek, beklenti ve arzuları değişiklik göstermektedir. Turizm pazarının artırılmasında bir fırsat olarak değerlendirilmesi gereken bu durum karşısında ülkeler, farklı turizm türlerini planlamak ve geliştirmek zorundadırlar (Gülyuva ve Kızılırmak, 2017: 102-103). Bu bağlamda turizm açısından temel faktör olan doğa, tarih, çevre kültür ve sanat gibi faktörler vazgeçilmez bir nitelik kazanmıştır (Duman vd., 2007: 213). Bu nedenle doğa turizmi kapsamında alternatif bir turizm çeşidi olan mağara turizminin de gelişmesine devam edeceği ve popülerliğinin artacağı söylenebilir.

Fakıllı Mağarası'nın yer aldığı Akçakoca, bünyesinde birçok doğal güzelliği ve kültürel mirası barındıran, düzenlenen birçok etkinlik ve coğrafi konumu itibariyle her yıl binlerce turisti ağırlayan Düzce ilinin ilçelerinden biridir. Karadeniz ile olan kıyı şeridinin büyük oranda plajlardan oluşması, Akçakoca'yı deniz, kum, güneşi kapsayan turizm faaliyetleriyle ön plana çıkarmaktadır. Ancak Akçakoca; mağaraları, şelaleleri, tarihi yapıları ve bölgeye özgü yiyecekleri ile birçok farklı turistik ürüne sahiptir. Bu araştırmaya konu olan Fakıllı Mağarası da deniz, kum, güneşin dışında ön plana çıkartılması gereken turistik ürünlerden birisidir.

\section{LITERATÜR ARAȘTIRMASI}

\section{Fakıllı Mağarasının Özellikleri ve Turizm Potansiyeli}

Şekil 1'de haritadaki konumu gösterilen Fakıllı Mağarası, Akçakoca ilçesinin 8 kilometre güney doğusundaki Fakıllı Köyü'nde bulunmaktadır. Adını bulunduğu köyden alan mağaranın toplam 
uzunluğu 1071 metre, ziyaretçiye açık alanı ise 350 metredir (http://www.akcakoca.bel.tr/). Bölge halkından edinilen bilgiye göre, Fakıllı Mağarası ilk olarak 1986 yılında ziyarete açılmıştır. Ancak bu yıllardaki ziyaretçi profilini genellikle yerel halk ve yakın çevreden bölgeye gelen kişiler oluşturmuştur. 2010 yılında ise mağaranın iç ve dış çevresinde yapılan çalışmalar ve yeni düzenlemelerle mağara turizme açılmıştır. Takip eden yıllarda mağaranın turizm potansiyelinin arttırılması için reklam ve pazarlama faaliyetlerine önem verilmiştir.

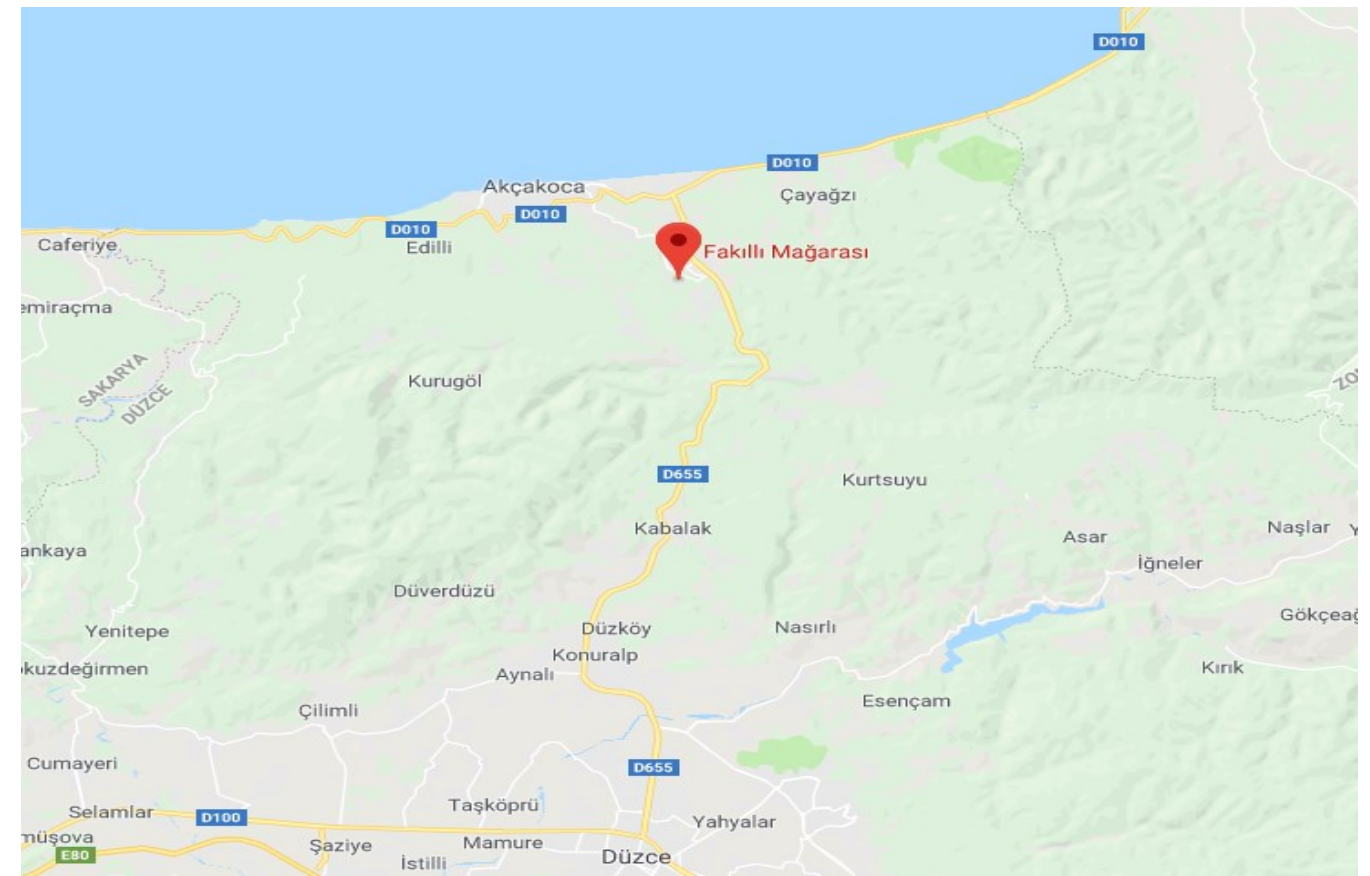

Şekil 1: Fakıllı Mağarasının Konumu

Kaynak: https://www.google.com.tr.

Fakıllı Mağarası'nın etrafı ve girişi yeşil alanlarla çevrilmiş doğal bir güzelliğe sahiptir. Mağaranın girişine giden yolda ve mağaranın giriş bölümünde ziyaretçilerin hoşça vakit geçirmesi, dinlenmesi, piknik yapması ve eğlenmesi için masa ve oturaklardan oluşan iki alan bulunmaktadır (Şekil 2).

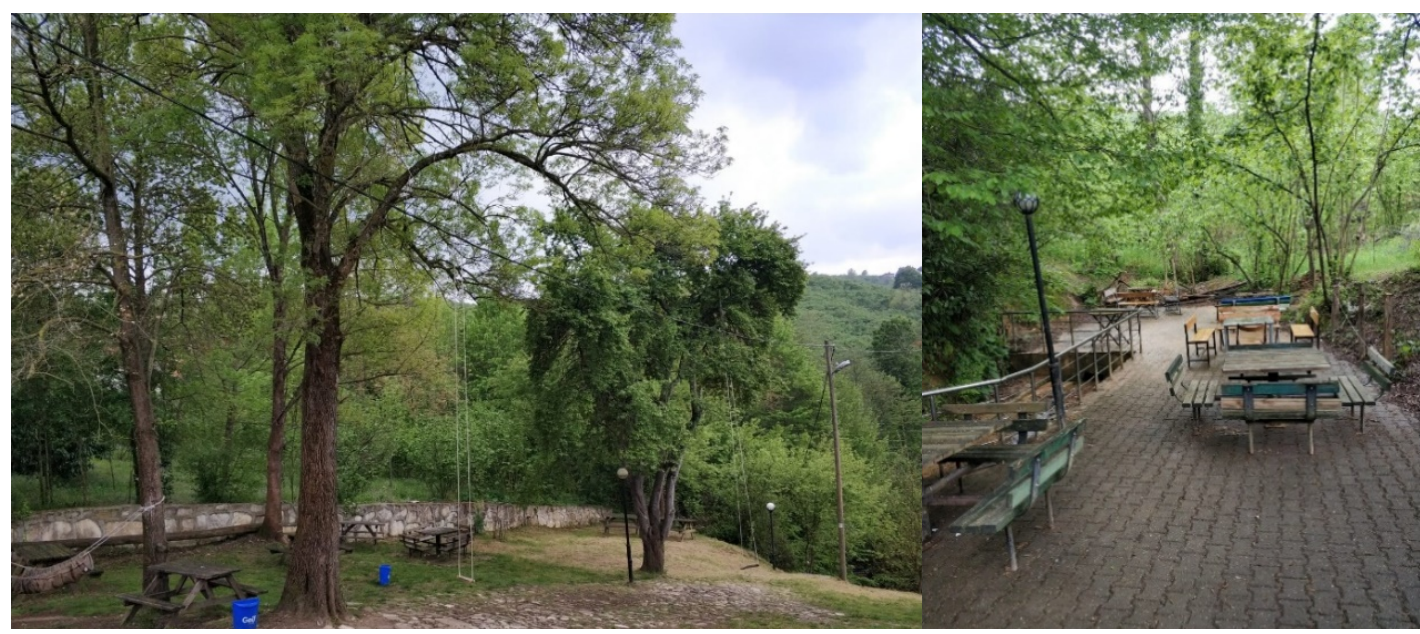

Şekil 2: Fakıllı Mağarasının Çevre Görüntüsü 
Mağara girişine yakın alandaki oturma alanlarının yan tarafında bulunan merdivenlerden inerek mağaranın giriş kapısına ulaşılmaktadır. Merdivenlerin olduğu yerde, yağışlı dönemlerde düden girişler ile önemli oranda su girişi bulunmaktadır. Mağaraya giriş yaptıktan sonra, mağaranın ana bölümlerine ulaşmak için uzun dar bir koridordan geçilmektedir (Şekil 3). Kültür ve Turizm Bakanlığı Kültür ve Tabiat Varlıklarını Koruma Bölge Kurulu Müdürlüğü tarafından birinci derecede sit alanı olarak tescillenen mağaranın içinde çeşitli yönlere giden galeriler, sarkıt ve dikitlerden oluşan birçok doğal özellik bulunmaktadır (http://www.akcakoca.bel.tr/).

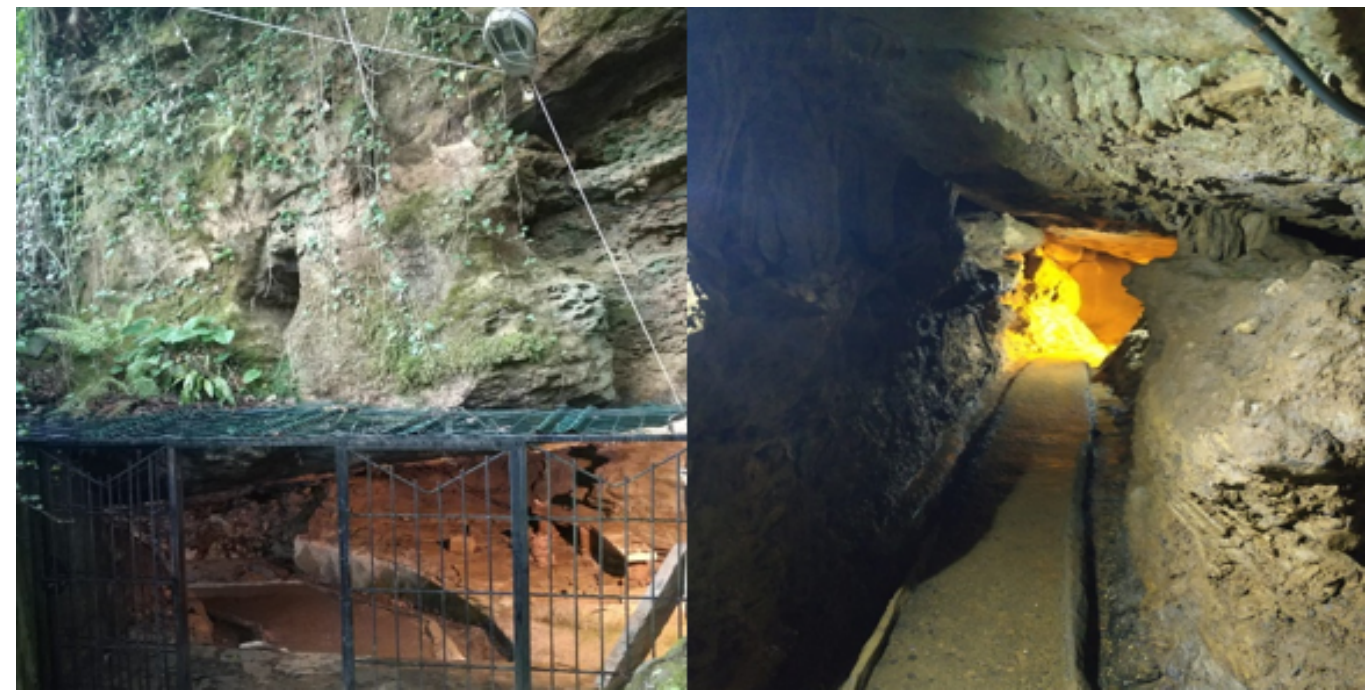

Şekil 3: Fakıllı Mağarasının Girişi ve Mağara İçinde Uzanan Koridor

Karstik mağaralar ve içlerinde bulunan şekiller binlerce yılda meydana gelmektedir. Bu şekillerin çeşitliliği ve görsel çekiciliği insanları hayran bırakmaktadır (Kopar, 2009: 80). Fakıllı Mağarası da sahip olduğu karstik şekiller ile görülmeye değer bir doğal oluşumdur. Damlataşı oluşumları bakımından zengin olması ve sahip olduğu hava ve atmosfer Fakıllı Mağarası'nı çekici kılan diğer özellikleridir.

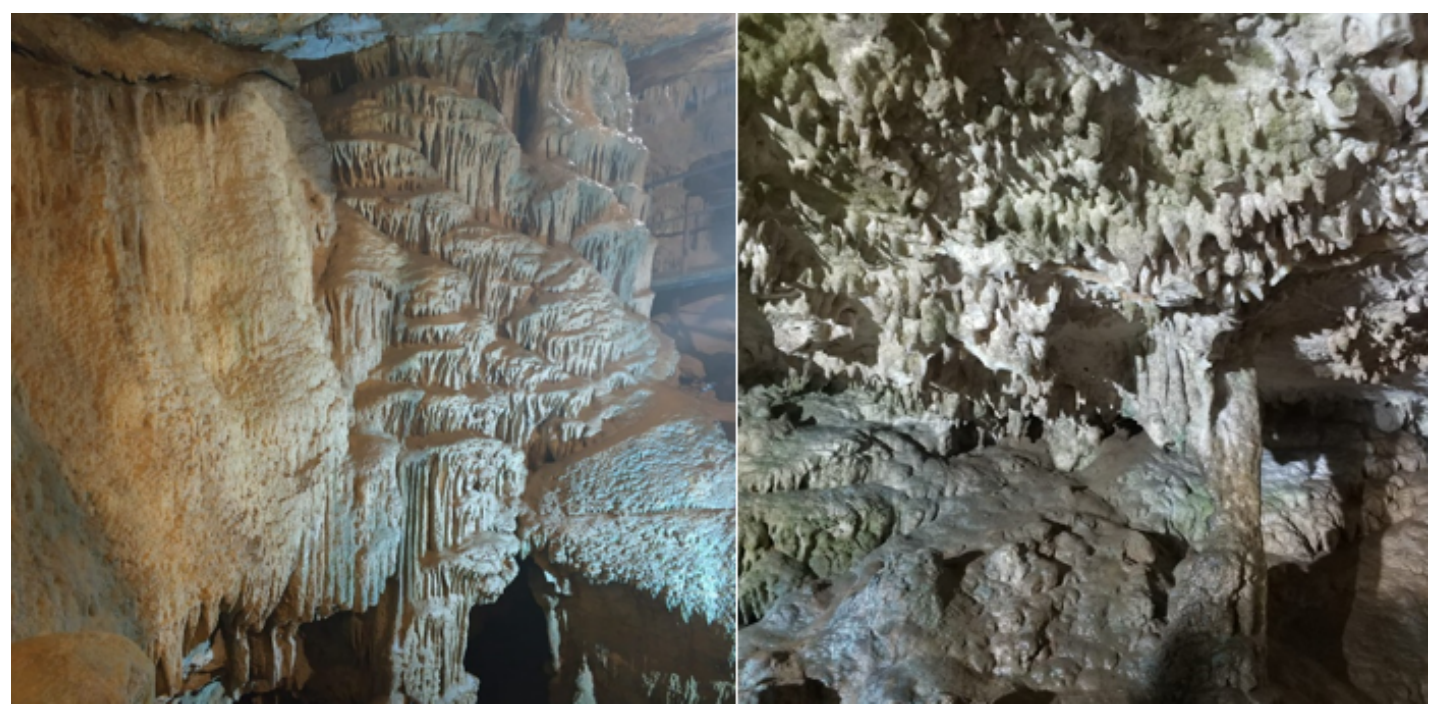

Şekil 4: Fakıllı Mağarasındaki Oluşumlara Ait Görüntüler

Birbirine bağlı iki bölümden oluşan mağaranın kuzey-güney veya KKD-GGB yönlü ana galerileri tabakaların doğrultusuna bağlı olarak gelişmişlerdir. Buna karşılık doğu-batı veya BKB-DGD 
yönlü bağlantı galerileri ise tabakaların eğim yönünde ve bunları kesen çatlaklar üzerinde uzanırlar. Bu şekliyle mağaranın kafesli bir yapısı vardır (https://www.kulturportali.gov.tr/). Deniz seviyesinden 100 metre yukarıda bulunan mağaranın ana giriş galerisi 5-10 metre genişliğe ve 56 metre tavan yüksekliğine sahiptir.

Fakıllı Mağarası, yüzeye yakın bir noktada bulunması nedeniyle yaz ve kış mevsimlerinde büyük farklılıklar gösteren nemli, sıcak ve serin bir havaya sahiptir. Mağaranın havasının astım ve nefes darlığı hastalığına iyi geldiği söylenmektedir (https://duzce.ktb.gov.tr/).

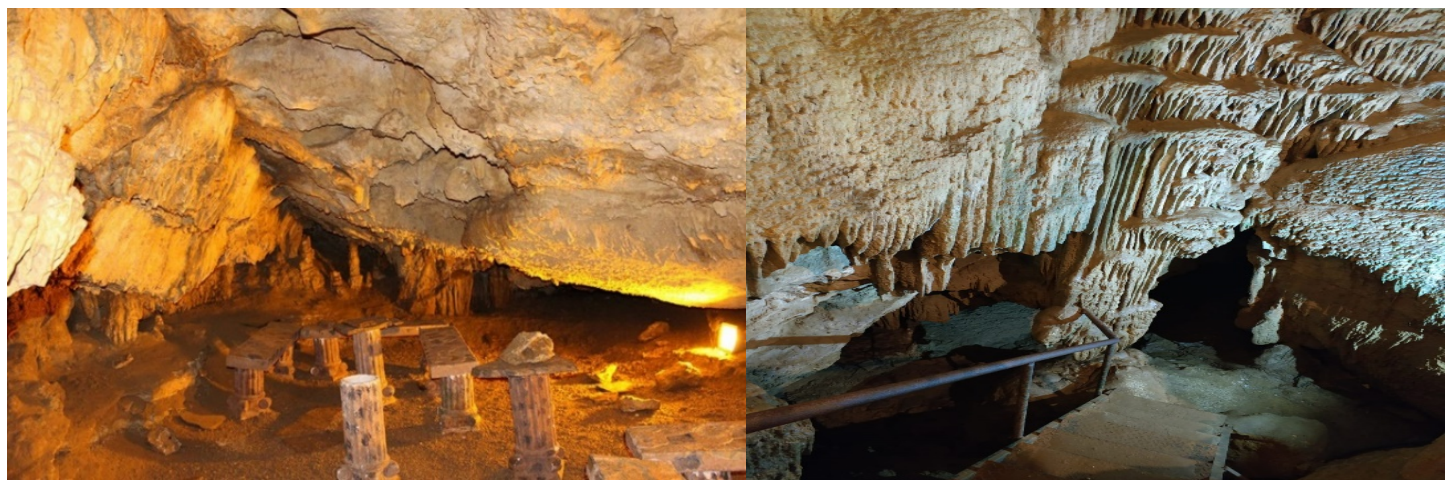

Şekil 6: Fakıllı Mağarası İçinden Bir Görünüm ve Fakıllı Mağarasının Ziyarete Açık Bölümünün Son Kismı

Çok dönemli gelişimi karakterize eden şekil ve yapılara sahip olan Fakıllı Mağarası yarı aktif bir mağaradır (https://duzce.ktb.gov.tr/). Mağara duvarlarında ve tavanında akma ve damlamalar devam etmektedir. Ayrıca zemin, kaygan bir yapıya sahiptir. Bu durum mağaradaki karstik şekillerin gelişiminin hâlâ devam ettiğinin belirtilerindendir.

İşletmesi özel şahıs tarafından yürütülen Fakıllı Mağarası'nı 2012 yılında Akçakoca Kaymakamlığı' nca yapılan açıklamaya göre 4325 kişi ziyaret etmiştir. Bu rakam aynı yıl Akçakoca'yı ziyaret eden turist sayısının yaklaşı \%3'üne denk gelmektedir. Mağarayı ziyaret eden turistler hakkında güncel verilere ulaşılamaması ve Fakıllı Mağarası' nın 2012 yılında çok az turist tarafından ziyaret edilmesi araştırmanın çıkış noktasını oluşturmuştur. Ancak resmi bir yazılı kaynak olmasa da araştırma sırasında katılımcılardan elde edilen bilgilere göre Fakıllı Mağarası'nın 2018 yılında yaklaşık 28 bin turist tarafından ziyaret edildiği öğrenilmiştir.

\section{METODOLOJI}

\section{Araştırmanın Amacı ve Önemi}

Araştırmanın amacı, Düzce İli Akçakoca İlçesinde yer alan Fakıllı Mağarası'na yönelik turizm talebini etkileyen faktörleri belirleyerek, bu talebin arttırılmasına yönelik öneriler sunmaktır. Bu kapsamda Fakıllı Mağarası'nın sahip olduğu turizm potansiyeli incelenmiş, bunun neticesinde ise alternatif bir turizm çeşidi olarak Akçakoca ilçesini ziyaret eden turistlerin mağara turizmine katılmasında etkili olan nedenler araştırılmış ve çözüm önerileri sunulmuştur.

Yapılan bu araştırma Fakıllı Mağarası'nın turizm potansiyeli hakkında bilgi vermesi, bu potansiyelin geliştirilmesine yönelik yapılabilecek olan çalışmaları ortaya koyması ve bu sayede Akçakoca ilçesinin turizm talebinin arttırılmasına yönelik sağlayacağı faydalar açısından önem taşımaktadır. Bununla birlikte Fakıllı Mağarası'nın mağara turizmi kapsamında geliştirilmesi sonucunda bölge halkına da ekonomik olarak sağlayacağı faydalar ile ilgili bilgi sunduğundan dolayı, yaşam standartlarının geliştirilmesi konusunda yol gösterici niteliktedir. 


\section{Araştırmanın Yöntemi ve Kısıtları}

Bu araştırmada amaca ulaşmak için iki yöntem kullanılmıştır. İlk olarak araştırmacı, araştırmaya konu olan Fakıllı Mağarası'nı ziyaret ederek katılımlı gözlem yönteminden yararlanmış, mağara ve yakın çevresi hakkında veri toplamıştır. Araştırmanın ikinci kısmında ise nitel araştırma yöntemlerinden görüşme tekniğinden yararlanılmıştır. Araştırma verilerini toplamak amacıyla Akçakoca ilçesinin turizm paydaşlarına yarı yapılandırılmış mülakat uygulanmış, bu görüşmelerden elde edilen veriler doğrultusunda GZFT analizi matrisi oluşturulmuştur.

Araştırmaya katılan turizm paydaşları; konu hakkında bilgi sahibi olan yerel yöneticiler, akademisyenler, sivil toplum kuruluşu yöneticileri ve bölgeyi ziyaret eden turistlerden oluşmaktadır. Mülakatlar gerçekleştirilmeden önce sorular hakkında katılımcılara bilgi verilmiştir. Araştırma kapsamında elde edilen gözlem ve yarı yapılandırılmış mülakat verileri karşılaştırılarak Fakıllı Mağarası'nın turizm talebini etkileyen faktörler ortaya çıkarılmaya çalışılmış ve çözüm önerileri sunulmuştur.

Bazı turizm paydaşlarının görüşme taleplerini reddetmeleri ve kabul edilen görüşme taleplerinin daha sonra turizm paydaşları tarafından iptal edilmesi araştırma sürecinde karşılaşılan kısıtlar olarak ifade edilebilir. 25 Nisan - 10 Mayıs arasında veri toplama süreci gerçekleştirilen bu çalışmada bölgedeki turizm sezonunun başlamamış olması nedeniyle yeterli sayıda turist ile görüşme yapılamamıştır. Aynı sebepten dolayı faaliyetlerine henüz başlamamış olan bir kısım turizm işletmesi yöneticileri de araştırmaya dâhil edilememiştir. Bölgenin turizm sezonunda daha geniş bir örneklem üzerinde farklı yöntemle yürütülecek çalışmalar, daha genel kanılara ulaşılmasını sağlayabilecektir.

\section{Araştırmanın Evren ve Örneklemi}

Araştırmanın evrenini Fakıllı Mağarası hakkında bilgi sahibi olan Akçakoca'daki merkezi ve yerel yönetim unsurlarının yöneticileri ile sivil toplum kuruluşlarının yetkilileri, akademisyenler ve ilçeyi ziyaret eden turistler oluşturmaktadır. Araştırma devam eden bir çalışmanın bir bölümünü oluşturduğundan ilk aşamada evreni temsilen kolayda örneklem yöntemi kullanılarak STK ve resmi kurum yöneticileri, akademisyen ve turistlerden oluşan 25 katılımcı ile görüşme gerçekleştirilmiştir.

\section{ARAŞTIRMANIN BULGULARI VE TARTIŞMA}

\section{Fakıllı Mağarası'nın Turizm Açısından Genel Değerlendirilmesi}

Araştırmaya katılan turizm paydaşlarına Fakıllı Mağarası'nın turizm açısından genel olarak değerlendirilmesine yönelik 3 soru sorulmuştur. Bu başlık altında, sorulara ilişkin verilen cevaplar değerlendirilmiş ve bazı paydaşların konu hakkındaki düşüncelerine yer verilmiştir.

Katılımclara, Fakıllı Mağarası' nın mağara turizmi kapsamında alternatif bir turizm çeşidi olarak yeterince tanıtımının yapılıp yapılmadığı hakkındaki düşünceleri sorulduğunda, 19 katılımcı yapılan tanıtım faaliyetlerinin yetersiz olduğunu belirtmiştir. Bunun nedenleri ise; yerel yönetim ve bölge halkının mağaraya ilgisiz olması, bölge halkının mağara turizmi hakkında bilinçsiz olması, mağara işletmesinin şahıs tarafından yürütülmesi ve mağaranın yeterince turizm potansiyeli bulunmaması olarak değerlendirilmiştir. 6 katılımcı tarafından ise yapılan tanıtım faaliyetleri yeterli bulunmuş ve web sitesi, broşür, sosyal medya, ulusal ve uluslararası fuarlar aracılığıyla bu faaliyetlerin gerçekleştirildiği ifade edilmiştir. 
Reklam ve tanitım faaliyetleri diğer tüm ürün ve hizmetlerde olduğu gibi turistik bir bölgenin de pazarlanmasında önemli rol oynamaktadır. Araştırmadan elde edilen bulgular dikkate alınd1ğında Fakıllı Mağarası için yürütülen reklam ve tanıtım faaliyetlerinin yetersiz olduğu söylenebilir. Bu durum bölgeyi ziyaret eden turistlerin Fakıllı Mağarası hakkında bilgi sahibi olma ihtimalini düşüreceği gibi mağaranın bilinirliğini de azaltacağından dolayı, reklam ve tanıtım faaliyetlerine önem verilmesi gerekliliği ortaya çıkmaktadır.

Günümüzde ve gelecekte Akçakoca'nın turizm potansiyelini arttırmada Fakıllı Mağarası'nın etkin bir rol oynayıp oynamayacağına ilişkin katılımcıların görüşleri sorulduğunda, 14 katılımcı etkili olabileceğini, 11 katılımcı ise etkili olmayacağını belirtmiştir. Mağaranın turizm potansiyeline olumlu bir etkide bulunabileceğini düşünen katılımcılar bunun; iyi bir şekilde yürütülecek tanıtım faaliyetleriyle, mağara içinde ve mağara çevresinde yapılacak düzenlemelerle, mağaranın tur kapsamına alınarak ve kültür, sağlık ve doğa turizmi kapsamında değerlendirilerek mümkün olabileceği üzerinde durmuşlardır.

Akçakoca'nın turizm potansiyeli üzerinde Fakıllı Mağarası'nın bir etkisi olmayacağını düşünen 11 katılımcı ise, Fakıllı Mağarası'nın sadece Akçakoca'ya gelen turistler tarafından ziyaret edileceğini, mağarayı görmek için Akçakoca'ya turist geleceğini düşünmediklerini belirtmişler, mağaranın bu kapsamda değerlendirilmesi ve yapılacak çalışmaların bu durumu göz önüne alarak yürütülmesi gerektiğini vurgulamışlardır.

Mağara turizmi, gün geçtikçe turistlerin daha çok ilgisini çeken alternatif bir turizm çeşididir. Mağara turizmine yönelik artan bu talebi değerlendirmek ve mağaralara özel ilgisi olan turistleri bölgeye çekmek için gerekli çalışmaların yapılması, bölgeye gelen ziyaretçi sayısının artmasında etkili olabileceği söylenebilir. Bu bağlamda, araştırmadan elde edilen bulgular incelendiğinde Fakıllı Mağarası'nın Akçakoca'nın turizm talebini arttırmada ektili olması için tanıtım ve pazarlama faaliyetleri ile iç ve dış çevre düzenlemelerinde gerekli çalışmaların yapılması gerektiği görülmektedir.

Araştırma kapsamında katılımcılara, Fakıllı Mağarası'nın mevcut turizm potansiyelini arttırmak için yapılabilecek faaliyetlerin ve çalışmaların neler olabileceği hakkındaki görüşleri sorulmuştur. Önem sırasına göre düzenlenmiş olan katılımcı görüşleri şu şekildedir:

(a) Tanıtım faaliyetlerine gereken önem verilmeli,

(b) Mağaranın iç ve çevre düzenlemesi yeniden ele alınıp geliştirilmeli,

(c) Mağaraya olan ulaşım kolaylaştırılmalı,

(d) Mağara hakkındaki bilgi daha çok detaylandırılmalı,

(e) Mağaraya ulaşım yolunu gösteren yön tabelaları daha dikkat çekici hâle getirilmeli,

(f) Mağara çevresinde turistlerin ihtiyaçlarına yönelik işletmeler hizmete açılmall,

(g) Bölgede faaliyetini sürdüren turizm işletmeleri ile iş birliği yapılmalıdır.

Katılımcı görüşlerinden elde edilen bu bilgiler, aynı zamanda Fakıllı Mağarası'nın turistler tarafından yeterince ilgi görmemesine neden olabilecek etkenler olarak değerlendirilebilir. Örneğin; Fakıllı Mağarası' nın tanıtım faaliyetlerine gereken önem verilmemesi neticesinde turistler mağaranın varlı̆̆ hakkında haberdar olamayabilirler. Öte yandan mağaranın sahip olduğu özelliklere ait bilginin detaylandırılması, turistler için mağarayı daha ilgi çekici bir hâle getirebilecektir. 


\section{GZFT (SWOT) Analizine İlişkin Bulgular}

Araştırmacıların yaptığı katılımlı gözlem tekniğine ek olarak, Fakıllı Mağarası'na yönelik GZFT analizinin yapılması amacıyla katılımcılara dört soru yöneltilmiştir. Konu hakkında bilgi sahibi olan katılımcıların sorulara verdikleri cevaplar ve konu hakkındaki görüşleri incelenerek Tablo 1 oluşturulmuştur.

Fakıllı Mağarası' nın turizm potansiyelinin arttırılmasıyla ilgili güçlü yönlerin belirlenmesine ilişkin soruya 17 katılımcı tarafından verilen "yerleşim yerine ve şehirlerarası yol güzergâhına yakın olması" cevabı, mağaranın en güçlü yönü olarak ortaya çıkmıştır. Bunu 15 katılımcının "mağaranın ilgi çekici bir yapıya ve atmosfere sahip olması", 12 katılımcının "mağaranın bulunduğu bölgeye ve mağaraya ulaşım yolunun doğal güzelliklerle iç içe olması", 9 katılımcının "sağlık ve doğa turizmi kapsamında kullanılabilir potansiyele sahip olması" ve 6 katılımcının "giriş ücretinin nispeten ucuz olması" olarak verdiği cevaplar izlemektedir. Ayrıca 2 katılımcı "mağaranın ziyarete açık bölümünün genişletilebilir olmasını" güçlü yönü olarak değerlendirmiş̧ir. Ancak yapılan görüşmelerde, geçmişte bu konuda araştırma ve çalışmalar yürütüldüğü, bunun sonucunda mağaranın kapalı kısmının ziyarete açılmasının güvenli olmayacağı öğrenilmiştir. Bu bağlamda, verilen bu cevap güçlü yönlerden biri olarak değerlendirilmemiştir.

Tablo 1: GZFT Analizi

\begin{tabular}{|c|c|}
\hline Güçlü Yönler & \\
\hline $\begin{array}{l}\text { - Mağaranın bulunduğu bölge ve mağaraya } \\
\text { ulaşım yolunun doğal güzelliklerle iç içe ol- } \\
\text { ması } \\
\text { - Mağaranın ilgi çekici bir yapıya ve atmosfere } \\
\text { sahip olması } \\
\text { - Yerleşim yerine ve şehirlerarası yollara ya- } \\
\text { kınlı̆ı } \\
\text { - Giriş ücretinin nispeten ucuz olması } \\
\text { - Sağlık ve doğa turizmi kapsamında kullanıla- } \\
\text { bilir potansiyele sahip olması } \\
\text { - Kısmen de olsa mağara içi ve çevresinin dü- } \\
\text { zenlenmiş olması }\end{array}$ & $\begin{array}{l}\text { - Mağara çevresinde turistlerin ihtiyaçlarını karşılaya- } \\
\text { bileceği veya vakit geçirebileceği herhangi bir turizm } \\
\text { işletmesinin bulunmaması } \\
\text { - Tanıtım ve pazarlama faaliyetlerinin yetersiz olması } \\
\text { - Rehberlik ve güvenlik hizmetinin bulunmaması } \\
\text { - Mağara hakkındaki bilginin yetersizliği } \\
\text { - Mağara içi düzenlenmelerin yetersiz ve yanlış olması } \\
\text { - Mağara işletmesinin şahıs tarafından yürütülüyor ol- } \\
\text { ması } \\
\text { - Bölgedeki turizm acenteleri ve oteller ile yeterince iş } \\
\text { birliği yapılmamış olması }\end{array}$ \\
\hline Fursatlar & Tehditler \\
\hline $\begin{array}{l}\text { - Akçakoca'ya olan turizm talebinin giderek } \\
\text { artması } \\
\text { - İstanbul, Ankara ve Bursa gibi büyük illere } \\
\text { yakın olması } \\
\text { - Yakın çevresinde yer alan diğer mağaralarla } \\
\text { birlikte gezilebilme şansı olması } \\
\text { - Akçakoca'da turistlerin ilgisini çekebilecek } \\
\text { doğal ve kültürel güzelliklerin bulunması } \\
\text { - Mağara turizmine olan talebin gün geçtikçe } \\
\text { artış göstermesi }\end{array}$ & $\begin{array}{l}\text { - Mağaraya yeteri kadar bakım çalışmasının yapılma- } \\
\text { ması } \\
\text { - Mağaranın ve işletmecisinin denetlenmemesi } \\
\text { - Mağaraya ilçeden toplu taşıma veya servis hizmeti- } \\
\text { nin bulunmaması } \\
\text { - Altyapı ve üstyapı ile çevre düzenlemesindeki eksik- } \\
\text { likler } \\
\text { - Mağarayı ziyaret eden turistler ve bölge halkında } \\
\text { mağara turizmi bilincinin yeterince gelişmemiş ol- } \\
\text { ması }\end{array}$ \\
\hline
\end{tabular}


Yer aldığı coğrafi konuma bağlı olarak Fakıllı Mağarası' nın hem ilçeye hem de şehirlerarası yol güzergâhına yakın olması, mağaranın ulaşılabilirliğini arttırmaktadır. Ulaşımın nispeten kolay sağlanabilmesi, mağaranın ziyaretçi sayısını arttırmak için değerlendirilmesi gereken bir konu olarak öne çıkmaktadır. Fakıllı Mağarası'nın iç ve dış çevresinde sahip olduğu doğal güzelliklerin turistler açısından birer çekicilik unsuru olarak değerlendirilebileceği, mağaranın turizm potansiyelinin arttırılmasında etkili olabilecek dikkat edilmesi gereken diğer bir konu olduğu söylenebilir.

"Tanıtım ve pazarlama faaliyetlerinin yetersiz olması", 19 katılımcı tarafından Fakıllı Mağarası'nın turizm potansiyelini etkileyebilecek zayıf yönlerden biri olarak değerlendirilmiştir. 15 katılımcı ise zayıf yönlerin belirlenmesine ilişkin soruya "mağara çevresinde turistlerin ihtiyaçlarını karşılayabileceği veya vakit geçirebileceği herhangi bir turizm işletmesinin bulunmaması" cevabını vermiştir. Bu cevapları 11 katılımcının "rehber ve güvenlik hizmetinin bulunmaması", 10 katılımcının "mağara hakkındaki bilgi yetersizliği", 10 katılımcının "mağara iç düzenlenmelerinin yetersiz ve yanlış olması", 9 katılımcının "mağara işletmesinin şahıs tarafından yürütülmesi" ve 8 katılımcının "bölgedeki turizm acenteleri ve oteller ile yeterince iş birliği yapılmamış olması" olarak verdiği cevaplar izlemiştir. Ayrıca "mağara içinde yer alan geçişlerin dar ve mağara galerilerinin küçük olması" 3 katılımcı tarafından zayıf yön olarak değerlendirilmiş, mağaranın turist ziyareti için düşük kapasiteye sahip olduğunu belirtilmiştir.

Fakıllı Mağarası' nın özellikle sosyal medya boyutunda olmak üzere broşür bastırılması ve fuar tanıtımları gibi hali hazırda yapılan tanıtım faaliyetlerinde güçlü yönleri daha fazla ön plana çıkarılmalıdır. Tanıtım açısından zayıf görünen bu yönünün güçlendirilmesinin, mağaranın turizm potansiyeli üzerine oldukça etkili olabileceği söylenebilir. Akçakoca'yı ziyaret eden turist profilinin büyük bir kısmını İstanbul ve Ankara gibi çevredeki büyük illerden gelenlerin oluşturması da yapılacak reklam ve tanıtım faaliyetlerinin bu illere yoğunlaşması gerektiğini göstermektedir.

Fakıllı Mağarası hakkındaki bilginin mağaranın çekiciliğine ve tanıtım faaliyetlerine katacağı etki düşünüldügünde oldukça sınırlı ve düşük düzeyde bulunmaktadır. Oysa Fakıllı Mağarası'nın tarihi, geçmiş yıllarda kimler tarafından nasıl kullanıldığı hakkında bilgilerin ve varsa hikâyesinin veya efsanesinin ortaya çıkarılması turistler tarafından daha ilgi çekici bulunmasına neden olacaktır. Bu nedenle gerekli araştırmalar yapılarak Fakıllı Mağarası hakkındaki bilgiler daha çok detaylandırılmalı ve bu bilgiler tanıtım ve pazarlama faaliyetlerinde kullanılmalıdır.

Fakıllı Mağarası' nın yakın çevresinde turistlerin çeşitli ihtiyaçlarını karşılayabilecekleri herhangi bir turizm işletmesinin bulunmaması, mağarayı ziyarette bulunan turistlerin memnuniyeti üzerinde önemli bir eksiklik oluşturabilecektir.

Fakıllı Mağarası'nın turizm talebini arttırabilecek hangi fırsatlara sahip olduğuna ilişkin bir diğer soruya katılımclar tarafından verilen cevaplar incelendiğinde; 20 katılımcının "Akçakoca ilçesine olan turizm talebinin giderek artması", 16 katılımcının "İstanbul, Ankara ve Bursa gibi büyük illere yakın olması", 14 katılımcının "Akçakoca' da turistlerin ilgisini çekebilecek doğal ve kültürel güzelliklerin bulunması", 10 katılımcının "Fakıllı Mağarası'nın yakın çevresinde yer alan diğer mağaralarla birlikte gezilebilme şansı olduğu" ve 9 katılımcının "mağara turizmine olan talebin gün geçtikçe artış göstermesi" cevabını verdiği görülmüştür.

Fakıllı Mağarası'nın sahip olduğu fırsatlar incelendiğinde, tanıtım ve pazarlama faaliyetlerinin öneminin bir kez daha ortaya çıktığı görülmektedir. Bu bağlamda, Akçakoca'yı ziyaret eden turistlerin ve Akçakoca'nın yakın çevresinde yer alan illerdeki bireylerin ve turizm işletmelerinin Fakıllı Mağarası hakkında bilgilendirilmesinde ve mağara turizmine karşı artan turizm talebinin değerlendirilmesinde tanıtım ve pazarlama faaliyetlerinin önemli rol oynayacağı söylenebilir. 
Fakıllı Mağarası' nın turizm talebini etkileyebilecek tehdit unsurlarının belirlenmesine yönelik bir diğer soruya ise 23 kişi ile katılımcıların büyük çoğunluğu "mağaraya yeterli bakım çalışmalarının yapılmaması" cevabını vermiştir. 19 katılımcı tarafından "mağaraya Akçakoca ilçesinden toplu taşıma veya servis hizmetinin olmaması" bir tehdit unsuru olarak değerlendirirken, 16 katılımcı "mağaranın yeterince denetlenmediğini" belirtmiştir.

Bu cevaplara ek olarak, "altyapı ve üstyapı ile çevre düzenlemesindeki eksiklikler" 15 katılımcı tarafından "mağarayı ziyaret eden turistlerin ve bölge halkının mağara turizmi bilincinin yeterince gelişmemiş olması" 10 katılımcı tarafından birer tehdit unsuru olarak görülmüştür. Ayrıca 2 katılımcı "mağaranın günümüzdeki haliyle sunduğu hizmetin turistler üzerinde kötü bir etki bırakabileceğini ve mağara imajını olumsuz etkileyebileceğini" belirtmiştir. Bunun sonucunda memnuniyetsiz ayrılan turistlerin çevresindeki diğer insanlara veya sosyal medya yoluyla mağara hakkında olumsuz geri bildirimlerde bulunabileceğinin üzerinde durmuşlardır.

Araştırma kapsamında yapılan gözlem sonucunda Fakıllı Mağarası' nın içindeki birçok alanın ziyaretçiler veya kişiler tarafından tahrip edildiği ve zarar verildiği görülmüştür. Mağara turizmi bilincine yeteri kadar sahip olunmamasının yanında mağarada konuya yönelik herhangi bir güvenlik önleminin alınmamasının bu sonuçlara neden olduğu düşünülmektedir.

\section{SONUÇ VE ÖNERILLER}

Akçakoca ilçesi her yıl binlerce turist tarafından ziyaret edilen, Batı Karadeniz bölgesinin önemli bir turizm destinasyonudur. Öncelikli turist çekim unsuru deniz ve kumsallar olsa da Akçakoca ilçesi, Fakıllı Mağarası'nın da içinde bulunduğu Ceneviz Kalesi, Aktaş Şelalesi ve Hemşin Camii gibi birçok kültürel ve doğal güzelliği bünyesinde barındırmaktadır. Akçakoca'nın sahip olduğu tüm bu turistik değerlerin uygun reklam ve tanıtım faaliyetleri kullanılarak turistlerin ilgisine sunulmasının bölgeye gelen ziyaretçi sayısının artmasında etkili olabileceği söylenebilir.

Çalışma kapsamında elde edilen verilere göre Fakıllı Mağarası ile ilgili tanıtım faaliyetlerinin yetersiz olması ve mağara işletme faaliyetlerinin şahıs tarafından yürütülüyor olması mağaranın turizm potansiyelini olumsuz şekilde etkilemektedir. Mağara işletmecisinin tanıtım faaliyetlerinde sinırlı kaynaklara ve bilgiye sahip olduğu göz önüne alındığında, işletmeci ile yerel yönetimlerin koordineli bir şekilde bu alandaki çalışmaların yürütülmesi gerektiği bu bağlamda önerilebilir.

Okonkwo vd., (2017) mağara turizminin, turizm gelişimine etkilerinin araştırılması için örnek bir mağara üzerine yaptığı çalışmada da sürdürülebilir mağara turizmi gelişimi için turizm uzmanları, idari yönetim ve ev sahibi topluluk arasında bir sinerjiye ihtiyaç duyulduğu belirtilmiştir. Böyle bir sinerjinin turizmin gelişmesinde ve tanıtımında tüm tamamlayıcı faktörlerin bir araya getirilmesine yardımcı olacağı belirtilmiştir. Bununla birlikte bölgenin kendi çabaları ile başaramadığı turizm gelişimine uygun olan mağara güçlendirmesi ve konumlandırması için de bu sinerjiye ihtiyaç duyulduğu söylenmiştir.

Bu bağlamda Fakıllı Mağarası'nın yerel gazete ve dergiler gibi tanıtım araçları kullanılarak yerel düzeyde tanıtımına önem verilmelidir. Böylece bölgeyi ziyaret eden turistler tarafından Fakıllı Mağarası'nın bilinirliği arttırılabilecektir. Ayrıca Akçakoca ilçesinde yer alan kültürel ve doğal güzellikleri bir araya getiren turların düzenlenmesi turistlerin birden çok deneyimi birlikte yaşamasına olanak sağlayacaktır. Öte yandan yerel ve yakın çevrede faaliyet sürdüren seyahat acenteleri ve otel işletmeleri ile iş birliği yapılmasıyla beraber Fakıllı Mağarası hakkında turistlere bilgi verilmesi ve yakın çevresinde yer alan diğer turizme açık mağaraları da kapsayan turlar düzenlenmesi, mağaranın bilinirliğini arttırmada önemli rol oynayacaktır. 
Yer aldığı coğrafyada birçok doğal güzellik ile iç içe bulunmasının yanında kendi içinde de sahip olduğu doğal güzelliklerin korunması ve Fakıllı Mağarası'nın mağara turizmi kapsamında sürdürülebilirliğinin sağlanması adına mağaranın iç ve dış çevresinde yapılacak düzenlemelere önem verilmelidir. Fakıllı Mağarası'nın bulunduğu bu doğal çevre ayrıca sağlık, spor ve doğa turizmi kapsamında da değerlendirilebilir.

Akçakoca ilçesi ile Fakıllı Mağarası arasındaki ulaşım yolunun büyük bir kısmının dere kenarından geçmesi, bu yola ayrı bir doğal güzellik katmaktadır. Turistlerin bu yol boyunca güvenli bir şekilde yürüyüş yaparak mağaraya ulaşması için düzenlemelerin yapılması, turistler için güzel bir doğa yürüyüşü deneyimi sağlayabilecek ve mağarayı ziyaret etmeyi çekici kılabilecektir.

Bununla birlikte Fakıllı Mağarası'nın havasının ve atmosferinin bazı solunum yolu rahatsızlıklarına iyi geldiği söylenmektedir. Bu nedenle sağlık turizmi kapsamında mağaranın sahip olduğu atmosfer ve hava, konusunda uzman kişilerce araştırılıp test edilmeli ve mağaranın sağlık açısından yararları ortaya konulmalıdır. Araştırma sonucunda bir takım olumlu sonuçlar elde edilir ise, bu durum sağlık turizmi kapsamında bir çekicilik unsuru olarak reklam ve tanıtım faaliyetlerinde ön plana çıkarılabilir.

Fakıllı Mağarası'nın çevresinde turistlerin özellikle yiyecek-içecek bağlamında olmak üzere çeşitli ihtiyaçlarına sınırlı cevap verebilecek az sayıda köy işletmesi bulunması, mağarayı ziyaret eden turistlerin memnuniyeti üzerinde önemli bir eksiklik olarak ortaya çıkmaktadır. Atsan ve Çetinsöz (2019) tarafından mağara turizmini tercih eden turistleri motive eden faktörlerin belirlenmesi amacıyla Aynalıgöl (Gilindire) Mağarası örneği üzerine yapılan çalışmada, gastronomi motive edici bir faktör olarak belirlenmiştir ve mağara çevresinde yiyecek-içecek işletmelerinin önemini ortaya koymuştur.

Fakıllı Mağarası'nda da bu tür işletmelerin eksikliği göz önüne alındığında; bölgenin doğal yapısına zarar vermeyecek şekilde turistlerin yeme-içme, konaklama, dinlenme ve alışveriş gibi ihtiyaçlarını karşılayabilecekleri turizm işletmelerinin hizmete açılması gerektiği görülmektedir. $\mathrm{Bu}$ kapsamda yerel halk ile iş birliği yapılmalı, yerel halk turizm ve mağara turizmi kapsamında bilinçlendirilerek mağaranın bulunduğu bölgede ekonominin gelişmesi ve bölgenin kültürel özelliklerinin turistlere tanıtılabilmesi için çalışmalar yapılmalıdır.

Hem ilçeye hem de şehirlerarası yol güzergâhına yakın olması, Fakıllı Mağarası'nın ulaşılabilirliğini arttırmaktadır. Bu kapsamda öncelikle, Akçakoca'yı turistlerin yoğun olarak ziyaret ettiği dönemlerde turistlerin mağaraya ulaşımını sağlamak amacıyla otobüs ya da servis hizmeti sunulmalıdır. Otobüs ya da servis hizmeti, kişisel ulaşım aracı olmayan turistleri taksi gibi özel ulaşım hizmetlerinin yüksek maliyetlerinden kurtararak Fakıllı Mağarası'nı ziyaret etmeyi daha cazip hale getirecektir.

Yapılan gözlem ve araştırma bulguları dikkate alındığında Fakıllı Mağarası'nın iç düzenlemesinde birçok eksikliğin ve yanlışlığın olduğu sonucu ortaya çıkmaktadır. Bunlar; mağara içinde herhangi bir uyarı levhasının bulunmaması, yürüyüş parkuru olarak normal beton malzeme ile oksitlenmeyle birlikte zehirlenmelere neden olabilecek demir malzeme kullanımı ve yanlış ışıklandırmadır.

Geçmişten günümüze mağara içinde bulunan beyaz odanın değişimine dikkat çeken katılımcılar, beyaz odanın rengini yavaş yavaş kaybettiğini belirtmiştir. Bu durum ışıklandırma başta olmak üzere mağara içi düzenlemesinin yeniden yapılması gerektiğini ortaya çıkartmaktadır. Öne çıkan bu eksiklikler ve yanlışlıklar, mağaranın içyapısı göz önünde bulundurularak uzmanlarca yeniden düzenlenmelidir. Örneğin; mağara zemininde mağaranın yapısına uymayan normal beton malzeme kullanmak yerine mağaradan elde edilmiş malzeme ya da doğal taşlar ile hazırlanmış 
bir karışım kullanılması, mağaranın doğal yapısını ve güzelliğini muhafaza etmesinin yanında görsel olarak da bir güzellik katacaktır.

Mağaranın içindeki birçok alan ve doğal oluşumlar ziyaretçiler veya kişiler tarafından tahrip edilmiş ve zarar görmüş durumdadır. Bu durumun önüne geçebilecek herhangi bir güvenlik önleminin alınmamış olması, mağaranın sürdürülebilirliğini tehdit etmektedir. Ayrıca mağarada, yaşanabilecek herhangi bir acil duruma müdahale edebilecek personel ve rehberlik hizmeti verebilecek personel de bulunmamaktadır.

Mağarada personel eksikliğinden kaynaklanan problemlerin önüne geçilmeli; mağaranın bakım ve temizlik çalışmalarının yapılması için mağara işletmecisi teşvik edilmeli, belirli periyotlarla denetimler yapılmalıdır. Türkiye'de mağara sporunun geliştirilmesine yönelik, bu sporu yapan profesyonellerin görüşlerini ortaya koymak amacıyla Benli vd. (2017) tarafından yapılan çalışmada da mağara turizminde eğitimin önemi ön plana çıarılmıştır.

Çalışma kapsamında mağara ziyaretlerinin eğitimli kişilerce gerçekleştirilmesi veya eğitimi olmayan kişilerin uzmanlar tarafından bilgilendirilerek ve rehberler eşliğinde yapılması gerektiği önerilmiştir. Ayrıca bölge halkının bilinçlendirilmesine yönelik çalışmaların, verilecek eğitimlerin kapsamına alınması gerektiği belirtilmiştir.

\section{KAYNAKÇA}

Akdağ, G. (2013). Bir Ekoturizm Aktivitesi Olarak Mağara Turizmi: Mersin Mağaraları Envanter Çalışması, 2. Doğu Akdeniz Turizm Sempozyumu, Çukurova Üniversitesi 19 Nisan 2013. Adana. ss: 180-192.

Arpacı, Ö., Zengin, B. ve Batman, O. (2012). Karamanın Mağara Turizmi Potansiyeli ve Turizm Açısından Kullanılabilirliği. Karamanoğlu Mehmetbey Üniversitesi Sosyal ve Ekonomik Araştırmalar Dergïi, 14 (23): 59-64.

Atsan, M. ve Çetinsöz, B. C. (2019). Mağara Turizmini Tercih Eden Turistleri Motive Eden Faktörler: Aynalıgöl (Gilindire) Mağarasına Yönelik Bir İçerik Analizi. Journal of Tourism Theory and Research, 5 (2): 260-272.

Benli, S., Can, M. ve Üst Can, Ç. (2017). Profesyonel Mağaracıların Gözünden Mağara Sporu ve Mağaraların Turizmde Değerlendirilmesi. Erzincan Üniversitesi Sosyal Bilimler Enstitüsü Dergisi ÖS-IV, 95-110.

Bekdemir, Ü., Sever, R., Uzun, A. ve Elmacı, S. (2004). Yıldızkaya Mağarası. Doğu Coğrafya Dergisi, 12: 309-324.

Duman, T., Kozak, M. ve Uysal, M. S. (2007). Turizmde Ürün Çeşitliliği Yoluyla Ürün Değeri Oluşturma: Türkiye' deki Arz Kaynakları Üzerine Bir İnceleme. Anatolia: Turizm Araştırmaları Dergisi, 18 (2): 206-214.

Gülyuva, D. S. ve Kızllırmak, İ. (2017). A Study on Tourism Potential of Ayvaini Cave. International West Asia Congress of Tourism. 28 September - 01 October 2017, Van, Turkey. ss: 102-106.

https://duzce.ktb.gov.tr/TR-211206/fakilli-magarasi.html [Erişim Tarihi: 15.05.2019].

https://sozluk.gov.tr/ [Erişim Tarihi: 01.05.2019].

http://www.akcakoca.bel.tr/turizm/gezilecek-yer/fakilli-magarasi/ [Erişim Tarihi: 14.05.2019].

https://www.google.com.tr/maps/@40.9873552,31.1551703,11z [Erişim Tarihi: 20.07.2019]. 
https://www.kulturportali.gov.tr/turkiye/duzce/gezilecekyer/akcakoca-fakilli-magarasi [Erişim Tarihi: 14.05.2019].

http://yigm.kulturturizm.gov.tr/TR-10335/magara-turizmi.html [Erişim Tarihi: 10.05.2019].

Kim, S. S., Kim, M., Park, J. and Guo, Y. (2008). Cave Tourism: Tourists' Characteristics, Motivations to Visit, and the Segmentation of Their Behavior. Asia Pacific Journal of Tourism Research, (13) 3: 299-318.

Kopar, İ. (2009). Aladağlar'da [Orta Toroslar (Yahyal1-Kayseri)] İki Fosil Mağara: Zindan-1 Köşk1 ve Zindan-1 Köşk-2 Mağaraları. Türk Coğrafya Dergisi, 53: 69-83.

Okonkwo, E. E., Afoma, E. and Martha, I. (2017). Cave Tourism and its Implications to Tourism Development in Nigeria: A Case Study of Agu-Owuru Cave in Ezeagu. International Journal of Research in Tourism and Hospitality (IJRTH), 3 (3): 16-24.

Öcal, T. ve Özcan, F. (2013). Çamlık Mağaraları ve Turizm Potansiyeli. Marmaya Coğrafya Dergisi, 28: 423-443.

Rindam, M. (2014). Cave Tourism: The Potential of Asar Cave as a Natural Tourism Asset at Lenggong Valley, Perak. SHS Web of Conferences 12: 1-9. 